\title{
Professor Norman Whitehouse
}

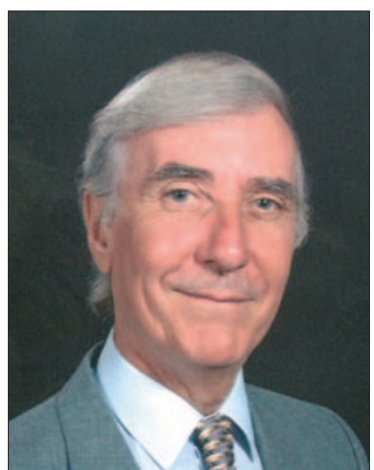

Friends and colleagues from the international dental community will be sad to learn of the death of Professor Norman Whitehouse on October 10th 2003.

Norman had a long and distinguished career in dentistry. During his professional life he worked hard, and with great success, to further the interests of the profession in Wales, the United Kingdom, and the European Union. He was known internationally as an innovative dental leader and was a highly skilled member of the dental public health speciality. In fact he was the second consultant appointed in this speciality in the UK. He will be remembered with great affection in a number of third-world countries where he helped to establish a proper, stepped approach to developing dental services, initiating university derived dental education systems, and establishing an appropriate professional structure based on his previous experience as Chief Executive of the British Dental Association. One recent example of this was the work he led in Peru based on the new dental school in Trujillo. At a speech marking his retirement in 1999, he said that although he never saw the benefits of fluoridation for the population of South Wales, he did at least achieve it for the children of northern Peru!

Norman Whitehouse was born in Walsall in 1938 and was educated locally at Queen Mary's Grammar School. He developed an interest in dentistry, became a student in Leeds and qualified in 1962. He entered general practice in Leeds as an associate. However, quite quickly he decided that he would like more involvement in the delivery of services to children and became a school dental officer in Shropshire. Obviously, his now legendary organisational skills were apparent even then, since he quickly became an area SDO in Norfolk. In 1969 he was appointed Chief Dental Officer in Nottingham, which was where I first met him in 1973.

From 1974 to 1986 Norman had a very happy time working in South Wales as Chief Dental Officer. I know that, during these years in Wales, much of the core of knowledge and experience was built up that subsequently stood him in good stead in his subsequent work at the national and international level. Indeed, he had a large impact on local and national dentistry following his appointment as Chief Administrative Dental Officer in South Glamorgan and East Dyfed health authorities. During that period he developed his first links with the University of Wales, lecturing in the dental school.

Perhaps, not surprisingly, his success in Wales caught the attention of the wider profession and he was appointed as Secretary and then the first Chief Executive of the British Dental Association from 1986 to 1993 where, amongst his many other duties, he represented the profession in negotiations at both national and EU levels. This was during a difficult time for the profession and his skills as a negotiator became renowned. Whilst Chief Executive, he was also elected as Secretary to the Commonwealth Dental Association, a job that very much suited his exceptional 'networking' abilities.

However, he never forgot his links with Wales, maintained his home here, and returned as Chief Administrative Dental Officer and Director of Dental Public Health in 1993. At the same time,
In summary, Norman Whitehouse made major contributions to the dental profession at local, national and international level...During all this strenuous international activity he remained very much a committed family man...All of us will fondly remember him.

he was appointed as General Manager of the Dental Hospital in Cardiff, thus bringing dental hospital and community services together for the first time. In 1993 he was also appointed as Dean of the Dental School and Professor of Dental Public Health at the University of Wales College of Medicine (UWCM). To have one person holding these three posts simultaneously facilitated a proper link between dental education and the provision of dental care to the community. The achievements flowing from this type of 'seamless' approach to university and NHS management, which was developed many years before the Follett Report, are too numerous to mention here. However, one example of the advantages of the seamless management approach was the significant expansion of what was one of the first dental outreach training programmes. His version of the 'seamless' approach to dental education and service was subsequently recognised in the EU as an example of 'good practice' and is now an increasingly copied model.

Norman Whitehouse had a distinguished career in UWCM and led the Dental School to high levels of achievement in the many areas of external assessment. Subsequently, he made major contributions as Vice Provost, then Pro Vice-Chancellor of UWCM. He led the Dental Hospital through the process where it (together with community dentistry partners) became the only independent dental trust in England \& Wales, and was the Chief Executive of the University Dental Hospital NHS Trust from 1995 to 1999.

He retired in 1999 but never slowed down. He was, until his death, Chairman of the Trustees of the Borrow Milk Foundation, was a member of Bro Taf Health Authority and was one of the three-person team from the European Union inspecting the dental standards of the 12 associate members of the EU.

In summary, Norman Whitehouse made major contributions to the dental profession at local, national and international levels. A real achievement was the demonstration that university and NHS management could not only work together but also could be managed together to a common purpose. In recognition of his many contributions to dentistry and to Wales, Norman Whitehouse was the first dentist to receive an honorary doctorate from the University of Wales in April of this year.

During all this strenuous international activity Norman remained very much a committed family man and was enormously proud of his wife, Barbara and their two children, Emma and Matthew. It is to them that his many friends, colleagues and the many to whom he was mentor, including myself, extend their sympathies. All of us will fondly remember him.

Malcolm Jones 